\title{
Effect of Azospirillum brasilense and mycorrhizal soil fungi on topinambur grown in a greenhouse
}

\begin{abstract}
To determine the effect of Azospirillum brasilense and soil mycorrhizal fungi on the nutrition of the Jerusalem artichoke crop (Helianthus tuberosus L.), evaluations of agronomic parameters and the health status of the plants were carried out, under greenhouse conditions. The tests were carried out, at the moment of the implantation of the culture: the tubers were inoculated with $A$. brasilense and with native mycorrhizal fungi, generating four treatments including the control and the co-inoculation of the consortium of the microorganisms under study (T0: control or control without inoculation; T1: inoculation with native $A$. brasilense; T2: inoculation with native mycorrhizal fungi and T3: joint inoculation with $A$. brasilense and native mycorrhizal fungi. The results indicate that co-inoculation with A. brasilense and with native mycorrhizal fungi increased plant growth in height, leaf area, biomass, dry matter, and yields significantly in greenhouse production. It was determined that the application of the selected microorganisms has a plant growth-promoting effect, increasing the productivity of cultivated topinambur in the greenhouse.
\end{abstract}

Keywords: interactions, co-inoculation, Helianthus tuberosus, Jerusalem artichoke, nutraceutical

\author{
Volume 8 Issue 4 - 202I \\ Di Barbaro Gabriela,' Andrada Horacio,' \\ Batallán Morales Silvana,' Espeche Acosta \\ Eliana,' Rizo Melisa,' Del Valle Eleodoro, ${ }^{2,3}$ \\ Brandán de Weht Celia ${ }^{4}$ \\ 'Faculty of Agricultural Sciences, National University of \\ Catamarca, Argentina \\ ${ }^{2}$ Faculty of Agrarian Sciences, National University of the Littoral, \\ Argentina \\ ${ }^{3}$ National Council for Scientific and Technical Research, \\ Argentina \\ ${ }^{4}$ Faculty of Agronomy and Zootechnics, National University of \\ Tucumán, Argentina
} Sciences, Nation Univicultur Maestro Quiroga, Argentina,

Email gabydibarbaro@yahoo.com.ar

Received: June 02, 2021 | Published: July 06, 2021

\section{Introduction}

The topinambur (Helianthus tuberosus L.) also known as tupinambo, pataca, Jerusalem artichoke, topi, and sweet potato sunflower, belongs to the botanical family of Asteraceae and is native to the central region of North America. ${ }^{1}$

The name was derived from the Tupinambá Tribe of Brazil, who was brought to Paris at the same time that the plant spread in Europe. In 1605 it was first introduced to France and then to various European countries; There it was widely used in food for humans and livestock. ${ }^{2}$ In Argentina, it was introduced at the beginning of the 20th century by European immigrants, where its cultivation was limited and of a family nature. ${ }^{2}$ The topinambur is cultivated for its following uses: horticultural, forage, and industrial, in addition in Turkey it is considered a medicinal plant where diabetic people consume the tubers. ${ }^{3}$

Human nutrition: It is considered that topinambur is a crop with great potential for human consumption as a horticultural species and the preparation of foods for diabetics and celiacs, due to its inulin content. The tubers are consumable fresh, they can transform them into flours for use in pastry, ${ }^{4}$ extract. ${ }^{5,6}$ But the traditional use of the tuber of topinambur is as a "gourmet" vegetable due to its qualities of healthy nutrition or as delicacies, having among its properties the fact that it does not contain gluten. The way to obtain a healthy food for daily consumption has been studied using $H$. tuberosus tubers as raw material, ${ }^{7,8}$ as well as the effect of culinary preparation on the carbohydrate composition, the texture, and the sensory quality of the tubers. ${ }^{8,9}$ It's chemical composition is rich in sugars, mainly inulin, which allows it to act as an excellent prebiotic. ${ }^{4,10,11}$

The viability of the production of topinambur puree was demonstrated, which is considered beneficial for health due to its high fructan content, whose minimum quantified value was $7.4 \%$ in the prepared product, and it is considered that it would be accepted by the population and produced on an industrial scale from instant puree. ${ }^{8,12}$ While Okada et al., ${ }^{13}$ determined that feeding H. tuberosus tubers improve glucose tolerance and liver lipid profile in rats fed a high-fat diet and concluded that topinambur tubers exert anti-fatty effects on the liver based on improvements in glucose tolerance and liver lipid profile. In France, topinambur tubers have been used for wine and beer production for many years. ${ }^{1}$

Animal feed: The aerial part is for forage use in summer and tubers in winter. The aerial part and the tubers have a great diversity of uses, among them as food for different types of livestock: bovines, pigs, goats. It constitutes an important part of the pig diet in Cuba. ${ }^{14}$ Papi et al. ${ }^{15}$ showed that the aerial parts of H. tuberosus could be used as a valuable forage in the diet of sheep. While Yildiz et al., ${ }^{16}$ studied the effect of $H$. tuberosus in the diet of laying hens and determined that the production, quality, and cholesterol content of eggs was not affected nor was there any adverse effect on the performance and quality of hens' eggs. Research conducted in Poland by Denisow et al., ${ }^{17}$ determined in $H$. tuberosus a high production of nectar and pollen, which is why it constitutes an attractive food resource for pollinators since flowering occurs at a time of low food supply for bees and wasps.

Industrial use: Numerous studies indicate the potential of topinambur to produce bioethanol ${ }^{18-22}$ and ethanol. ${ }^{23,24}$ It has advantages over other crops, mainly due to its high biomass yield. Previous research studies reported that 45001 of ethanol are obtained from $50 \mathrm{t}$ of $\mathrm{H}$. tuberosus tubers ${ }^{25}$ Other research in Spain Fernánde ${ }^{26}$ reported that in general terms 11 of ethanol can be obtained from $12 \mathrm{~kg}$ of topinambur tubers. While in experiments carried out in the province of Mendoza, it was possible to obtain $11 \mathrm{of}$ alcohol from $11 \mathrm{~kg}$ of topinambur tubers.

Research on the processing of $H$. tuberosus biomass, allowed the extraction of commercially interesting phenolic acids, as natural 
antioxidants for food, with pharmaceutical and cosmetic applications, and as fungicides. ${ }^{27}$ Meanwhile, Prusov et al. ${ }^{28}$ determined the potential of topinambur stems for cellulose production.

Rubel et al., ${ }^{29}$ studied different methodologies extracting higher inulin yields from topinambur tubers, as well as the optimal conditions to obtain a stable powder product. They described an extraction and drying method to obtain carbohydrate-rich inulin that can be applied on an industrial scale, and they estimated that freeze-drying is a method that should be considered as a drying alternative taking into account the cost and production time.

Other uses: H. tuberosus can be considered as an alternative crop to use as a promising species due to its multipurpose and an important source of raw material for various industries. Currently, work is being done on the extraction of different chemical compounds (such as sugars, 5-hydroxymethylfurfural, levulinic acid, inulin, phenolic compounds such as chlorogenic acid, gallic acid, salicylic acid, and caffeic acid, in addition to terpenes and flavones) that are found in $H$. tuberosus plants and the development of efficient and lowcost extraction and purification techniques. ${ }^{27,30-33}$ Different works mentioned below can support the possible use of topinambur as a raw material in the fields of biofuels and chemical product production.

A simple and efficient method for the separation of chlorogenic acid from the extract of $H$. tuberosus leaves was studied. Topinambur leaves were found to exhibit remarkable antimicrobial, antifungal, and anticancer activities. Phytochemical studies have revealed that polyphenols, especially chlorogenic acid, have been considered responsible for these human health benefits. Chlorogenic acid (3-0-caffeicoylkinic acid, 3-CQA), has recently received significant attention due to its wide spectrum of pharmacological properties that include anticancer, antioxidant, anti-inflammatory, hypoglycemic, and hepatoprotective agents, widely used in the pharmaceutical and food industries, and cosmetics. It is also a promising compound used as a precursor for the development of drugs that can control the HIV virus, AIDS. The sources of chlorogenic acid are limited, hence the importance of the production of $\mathrm{H}$. tuberosus leaves, as a source of raw material to extract $3-\mathrm{CQA} .{ }^{33}$

Chen et al., ${ }^{34}$ analyzed the antifungal activity of phenolic substances extracted from $H$. tuberosus leaves and investigated their potential use to improve the preservation of stored fruits and vegetables through the development of treatments with new natural antifungal agents. Their results indicate that topinambur leaves could be a potential source of natural fungicides.

Judprasong et al., ${ }^{35}$ evaluated the content of nutrients and toxic substances in tubers of $H$. tuberosus that are commonly consumed. This study determined the nutrients, chemical pollutants (insecticide residues and heavy metals), and naturally occurring toxic substances (nitrate, nitrite, cyanide, oxalate, phytate, and trypsin inhibitor) in topinambur tubers grown in four provinces of Thailand. All samples contained considerable amounts of fructans and dietary fiber, as well as potassium and iron. All samples had very low amounts of insecticide residues and naturally occurring toxins (cyanide and trypsin inhibitor, as well as $\mathrm{Pb}, \mathrm{Cd}$, nitrate, and nitrite, as well as oxalate and phytate. Important information on food composition and establishing the safety of its consumption of tubers of topinambur fundamentally.

The use of topinambur plants in phytoremediation techniques is currently being studied. Experiments developed by Willscher et al., ${ }^{36}$ indicate that $H$. tuberosus represents a species of plant suitable for phytoremediation technologies due to its ability to extract heavy metals, such as $\mathrm{Mn}, \mathrm{Zn}, \mathrm{Cd}$, and $\mathrm{Ni}$, in addition to growing in soils at different $\mathrm{pH}$ levels (4 to 6). Therefore, they consider it as a promising species to achieve the success of phytoremediation of soils affected by the mining and is contaminated with heavy metals. Marzec et al., ${ }^{37}$ determined that $H$. tuberosus plants can be used successfully in wastewater treatment plants, achieving high efficiency in the removal of suspended solids and, due to their high potential for biomass production, they can also be exploited as a bioenergetic resource. Also, the viability of agricultural crop residues of $H$. tuberosus, Helianthus annuus and Silphium perfoliatum was investigated, as alternative raw materials for the production of boards, to be used in the construction of furniture. They achieved boards with acceptable yields, although with properties below conventional fir particle boards. The relevant finding for industrial applications was that the boards produced from particles of agricultural residues joined with certain resins fully comply with the European regulations for use in dry conditions. This means that the particle boards of agricultural residues of the aforementioned crops have physical and mechanical properties that make them suitable to be used in the production of furniture..$^{38}$ Due to the characteristics of its stems, topinambur was used for the conditioning of phytopathological material and to make very precise cuts of fresh material that allow observation. ${ }^{39}$

Therefore, topinambur is a potential raw material for the sustainable production of bioenergy, which includes biofuels such as bioethanol, biobutanol, biogas, and others, as well as precursors for the development of medicines, cosmetics, and food mainly and in sanitation procedures of soils contaminated with heavy metals.

Therefore, topinambur is considered a multipurpose crop used for human food consumption, with pharmaceutical applications, for the production of biomass for forage and bioenergy. In addition, to brew beer and meeting the food demand of pollinating insects, it is an important raw material for its environmental benefits and its agronomic performance. For all the aforementioned reasons, it is considered valuable to increase the production of topinambur through the incorporation of more productive and profitable cultivation technologies such as the use of biofertilizers, which in turn allows to reduce production costs and reduce the use of agrochemicals.

Biofertilizers can contain one or more selected microorganisms, which can be applied to the seed or the soil to increase its density and its association with the root system of the plant to promote its nutrition. This improves the vegetative and productive development of the plant. The most widely used microorganisms for their potential contribution to plant development are the rhizobacteria $A$. brasilense and the arbuscular mycorrhizal fungus Glomus intraradices. ${ }^{40}$

Therefore, the objective of this work was to evaluate the effect of $A$. brasilense and native soil mycorrhizal fungi on the nutrition of the topinambur (Helianthus tuberosus L.) crop, by determining agronomic parameters and the health status of the plants.

\section{Materials and methods}

The treatments carried out on topinambur were:

- T0: Control (not inoculated).

- T1: Inoculation with A. brasilense.

- T2: Inoculation with native mycorrhizal fungi.

- T3: Joint inoculation with $A$. brasilense and native mycorrhizal fungi. 
The inoculated treatments consisted of applying the selected microorganisms to the topinambur tubers, by immersing them in the inoculant just before implantation. The propagules of the control treatments were placed in sterile tap water. Topinambur tubers $(H$. tuberosus) of about 10 grams were used.

The native strain Pi 8 of $A$. brasilense was used, isolated from the endorhizosphere of paprika (Capsicum annum var. Elephant trunk) grown in the Province of Catamarca, whose identification was made biochemically and molecularly. ${ }^{41-43}$ The concentration of $A$. brasilense used for the inoculations was $5 \times 10^{7}$ azosp. $\mathrm{mL}^{-1}$ quantified in a Neubauer chamber. ${ }^{44}$

The inoculum of mycorrhizal fungi native to the province was constituted by roots of Melilotus officinalis L., Avena sativa L., Hordeum vulgare L., Secale cereale L., Panicum maximun Jacq. and Cenchrus ciliaris L. colonized by these. The percentage of mycorrhizal colonization of the roots used as inoculum was $81.38 \%$, estimated by the method of line intersections and microscopic observation of roots by Sieverding ${ }^{45}$ and Mc Gonigle et al. ${ }^{46}$

Two experiments were carried out in a greenhouse, with unsterilized soil. 5-liter containers and soil from the agricultural area of the Central Valley of the Province of Catamarca (sand: 73.85; clay: 8\%; silt: $18.2 \%$; $\mathrm{pH}$ : 7.5; MO: 5.72\%). A drip irrigation system was installed to irrigate the topinambur crop. Containers were filled with the same volume of sieved soil, watered with the same amount of water and after the implantation of the different treatments, it was labeled and a layer of sterile perlite was added to avoid contamination and transfer of microbial inoculums between the plants pots. The containers were later moved to the greenhouse.

The experimental design was completely randomized with 15 repetitions per treatment. At the end of the crop cycle, they recorded the following data: plant height; the number of stems; leaf area index (IAF), ${ }^{47}$ fresh weight (PF), dry (PS), and percentage of dry matter (\% $\mathrm{DM}$ ) of stems, leaves, roots, tubers, and whole plant; the number of tubers per plant; average weight and tuber yield. With the data of dry weight (PS) and fresh weight (PF), the $\%$ of dry matter (\% DM = PS x 100 / PF) was calculated, both for stems, tubers, roots, and other parts of the plant.

The results were statistically analyzed by analysis of variance (ANOVA) and the means were compared using Fisher's LSD (Least Significant Difference) test at a significance level of 0.05 using the Infostat statistical program. ${ }^{48}$

\section{Results}

Two experiments were carried out. The extraction and evaluation of Experiment I of the topinambur crop was carried out 7 months after planting (October to May), while Experiment II at 3 months (from August to October).

Plant height: statistically significant differences were detected between the treatments of the two experiments. The plants inoculated with $A$. brasilense and mycorrhizal fungi (T3) presented higher heights during the entire crop cycle (Table 1).

Table I Comparison of agronomic parameters of topinambur (number, fresh weight, dry weight, dry matter and height of stems) produced in greenhouse with unsterilized soil. (Experiment I: 7 months of planting; Experiment II: 3 months of planting)

\begin{tabular}{|c|c|c|c|c|c|}
\hline & \multirow{2}{*}{ Variable } & \multicolumn{4}{|l|}{ Treatments } \\
\hline & & Control & Azospirillum & Mycorrhizae & Azosp.+Myco. \\
\hline \multirow{3}{*}{ 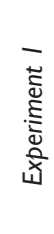 } & Nro. & $2,00 \pm 1,05$ a & $5,30 \pm 2,67 \mathrm{c}$ & $4,90 \pm I, 60$ bc & $3,60 \pm 1,07$ b \\
\hline & $\begin{array}{l}P F(g) \\
P S(g) \\
M S(\%)\end{array}$ & $\begin{array}{l}34,84 \pm 5,84 \mathbf{a} \\
18,89 \pm 3,24 \text { a } \\
54,21 \pm 1,84 \mathbf{b}\end{array}$ & $\begin{array}{l}44,66 \pm 17,67 \mathbf{a} \\
21,23 \pm 9,06 \mathbf{a} \\
46,47 \pm 8,39 \mathbf{a}\end{array}$ & $\begin{array}{l}45,49 \pm 12,97 \mathbf{a} \\
22,69 \pm 6,33 \mathbf{a} \\
50,49 \pm 6,35 \mathrm{ab}\end{array}$ & $\begin{array}{l}42,10 \pm 21,66 \mathbf{a} \\
19,52 \pm 11,83 \mathbf{a} \\
47,11 \pm 13,07 \mathbf{a b}\end{array}$ \\
\hline & Height $(\mathrm{cm})$ & $42,00 \pm 5,42$ a & $69,00 \pm 18,09$ b & $68,30 \pm 18,89$ b & $78,30 \pm 8,99$ b \\
\hline \multirow{3}{*}{ 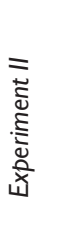 } & Nro. & $3,00 \pm 1,0 \mathbf{a}$ & $3,00 \pm 1,00 \mathrm{a}$ & $3,30 \pm 0,5 \mathbf{a}$ & $3,60 \pm 1,5$ a \\
\hline & $\begin{array}{l}P F(g) \\
P S(g) \\
M S(\%)\end{array}$ & $\begin{array}{l}9,00 \pm 1,0 \mathrm{a} \\
6,8 \pm 0,5 \mathrm{a} \\
36, I \pm 2,5 \mathrm{a}\end{array}$ & $\begin{array}{l}21,93 \pm 0,04 \mathrm{ab} \\
7,96 \pm 0,01 \mathrm{ab} \\
36,32 \pm 0,70 \mathrm{a}\end{array}$ & $\begin{array}{l}26,30 \pm 1,30 \mathbf{b} \\
9,5 \pm 0,4 \mathbf{b} \\
36,1 \pm 0,1 \mathbf{b}\end{array}$ & $\begin{array}{l}32,9 \pm 5,5 \text { c } \\
12,3 \pm 2,0 \text { c } \\
37,5 \pm 0,6 \text { a }\end{array}$ \\
\hline & Height $(\mathrm{cm})$ & $64,00 \pm 4,5$ a & $67,00 \pm 2,00 \mathrm{ab}$ & $68,60 \pm 2,5 \mathrm{ab}$ & $72,6 \pm 2,5 \mathbf{b}$ \\
\hline
\end{tabular}

Uncommon letters in the same variable denote significant differences according to the LSD test (Minimum significant difference) for $P<0.05$

Number of stems: In the inoculated treatments (T1 and T2) the highest number of aerial stems were observed, registering significant differences for the control treatment (T0) in experiment I. However, these differences were not observed in experiment II, being observed in plants of 3 months of cultivation of the different treatments, a similar number of aerial stems (Table 1).

Percentage of dry matter of aerial stems: Significant statistical differences were obtained between the treatments, the highest percentages of dry matter of stems were observed with greater frequency in the treatments with inoculation of mycorrhizal fungi only (T2) (Table 1). The highest values of fresh weight (FP) and dry weight (PS) of stems were observed in the inoculated plants (T2 and T3), however, statistically, significant differences were registered for the control plants, in experiment II (Table 1).

Number of tubers per plant: The number of tubers per plant is higher in the inoculated treatments, however, significant statistical differences were only recorded between treatments $\mathrm{T} 3$ and $\mathrm{T} 0$ in one of the experiments (Table 2). It was observed that the maximum number of tubers per plant grown in pots is well below those obtained in field experiments. ${ }^{49} \mathrm{It}$ is due to the limitations of the volume of soil contained in the pots, for which the plants have less availability of nutrients and would not reach the size as if it were grown in the field. 
Table 2 Comparison of agronomic parameters of topinambur (number, fresh weight, dry weight, dry matter, average weight and tuber yield) produced in greenhouse with unsterilized soil. (Experiment I: 7 months of planting; Experiment II: 3 months of planting)

\begin{tabular}{|c|c|c|c|c|c|}
\hline & \multirow{2}{*}{ Variable } & \multicolumn{4}{|l|}{ Treatments } \\
\hline & & Control & Azospirillum & Mycorrhizae & Azosp.+Myco. \\
\hline \multirow{4}{*}{ 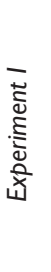 } & Nro. & $2,3 \pm 1,2 \mathbf{a}$ & $5, I+4,6 b$ & $3,7 \pm 2,0 \mathrm{ab}$ & $5,3 \pm 2,4 \mathbf{b}$ \\
\hline & $\begin{array}{l}P F(g) \\
P S(g) \\
M S(\%)\end{array}$ & $\begin{array}{r}4,19 \pm 2,7 \mathbf{a} \\
0,78 \pm 0,5 \mathbf{a} \\
|8,7| \pm 1,1 \mathbf{a}\end{array}$ & $\begin{array}{l}44,48 \pm 59,7 \mathbf{b} \\
10,24 \pm 14,0 \text { ab } \\
24,10 \pm 14 \text { a }\end{array}$ & $\begin{array}{l}30,79 \pm 4 \mid, 8 \mathrm{ab} \\
5,85 \pm 8,3 \mathrm{ab} \\
\mid 8,86 \pm 2,1 \mathrm{a}\end{array}$ & $\begin{array}{l}41,76 \pm 42,3 \mathrm{ab} \\
9,18 \pm 10,4 \mathrm{ab} \\
20,95 \pm 2,5 \mathrm{a}\end{array}$ \\
\hline & $P M(g)$ & $1,90 \pm 0,5 \mathbf{a}$ & $5,27 \pm 4,5$ ab & $5,93 \pm 6,4 \mathrm{ab}$ & $6,4 \mathrm{I} \pm 4,9$ b \\
\hline & Rdto. $\left(K g . h a^{-1}\right)$ & $85,45 \pm 56,4 \mathbf{a}$ & $907,79 \pm 1219,7 \mathbf{b}$ & $628,28 \pm 854$, Ib & $852,28 \pm 864,0 \mathbf{b}$ \\
\hline \multirow{4}{*}{ 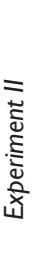 } & Nro. & $3,0 \pm 1,0 \mathbf{a}$ & $4,60 \pm 0,5 \mathbf{a}$ & $3,00 \pm 1,0 \mathbf{a}$ & $3,3 \pm 2,0 \mathbf{a}$ \\
\hline & $\begin{array}{l}P F(g) \\
P S(g) \\
M S(\%)\end{array}$ & $\begin{array}{l}7,0 \pm 1,2 \mathbf{a} \\
1,4 \pm 0,2 \mathbf{a} \\
18,6 \pm 4,8 \mathbf{a}\end{array}$ & $\begin{array}{l}15,7 \pm 0,3 \mathbf{b} \\
3,4 \pm 0,1 \mathbf{b} \\
18,5 \pm 6,7 \mathbf{b}\end{array}$ & $\begin{array}{l}8,5 \pm 2,0 \mathbf{a} \\
1,8 \pm 0,4 \mathbf{a} \\
29,9 \pm 21,1 \mathbf{b}\end{array}$ & $\begin{array}{l}9,5 \pm 5,7 \mathbf{a} \\
2,0 \pm 1,3 \mathbf{a} \\
41,2 \pm 53,4 \mathbf{a}\end{array}$ \\
\hline & $P M(g)$ & $2,4 \pm 0,4 \mathbf{a}$ & $3,4 \pm 0,5 \mathbf{b}$ & $2,9 \pm 0,3 \mathrm{ab}$ & $2,9 \pm 0,1 \mathrm{ab}$ \\
\hline & Rdto. $\left(K g \cdot h a^{-1}\right)$ & $143,5 \pm 25,8 \mathbf{a}$ & $321,0 \pm 7,1$ b & $173,4 \pm 40,9$ a & $194,5 \pm 1 \mid 8,0 \mathbf{a}$ \\
\hline
\end{tabular}

Uncommon letters in the same variable denote significant differences according to the LSD test (Minimum significant difference) for $\mathrm{P}<0.05$

Weight of tubers per plant: The highest weights of tubers per plant of topinambur were obtained in the treatments with the inoculation of the A. brasilense consortium and mycorrhizal fungi (T3), where statistically significant differences were observed between the microbial co-inoculation treatments (T3) and the control treatments (T0) (Table 2).

Percentage of dry matter of the tubers: A higher percentage of dry matter was determined in the tubers of the inoculated treatments, mainly with the co-inoculation of the microbial consortium (T3), observing statistically significant differences for the controls (T0) (Table 2).

Average weight of the tubers: The larger tubers, with the highest average weight, were observed in the inoculated treatments, registering significant statistical differences for the control treatment
(T0) (Table 2). Very small tubers were obtained that could be used as "seeds" since they achieved physiological maturation and can generate a new plant.

Yield (kg or $\mathbf{t}$ of tubers per $\left.\mathbf{h a}^{-1}\right)$ : The highest yields were achieved with the inoculation of the microbial consortium made up of $A$. brasilense and mycorrhizal fungi (T3) (Table 2). However, yields much lower than those obtained in field trials were achieved. ${ }^{49}$

Leaf area index (IAF): In the topinambur plants from the inoculated treatments, the highest IAFs were determined, establishing statistically significant differences in favor of the inoculated treatments compared to the controls only in experiment II (Table 3). However, the natural fall of leaves in older plants may explain that in experiment II the statistical significance of the IAF results was not recorded.

Table 3 Comparison of agronomic parameters of topinambur (leaf area index, fresh weight, dry weight and dry matter of leaves and roots) produced in greenhouse with unsterilized soil. (Experiment I: 7 months of planting; Experiment II: 3 months of planting)

\begin{tabular}{|c|c|c|c|c|c|}
\hline & \multirow{2}{*}{ Variable } & \multicolumn{4}{|l|}{ Treatments } \\
\hline & & Control & Azospirillum & Mycorrhizae & Azosp.+Myco. \\
\hline \multirow{6}{*}{ 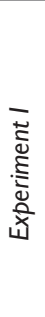 } & $\operatorname{IAF}\left(\mathrm{cm}^{2}\right)$ & $22|I, 99 \pm 3| 1,72 \mathrm{a}$ & $2597,20 \pm 904,72$ a & $2860,10 \pm 1033,5$ a & $2493,06 \pm 1335,36 \mathrm{a}$ \\
\hline & $P F_{\text {leaf }}(g)$ & $39,57 \pm 5,58 \mathbf{a}$ & $46,46 \pm 16,36 \mathbf{a}$ & $51,06 \pm 18,49$ a & $44,60 \pm 23,89$ a \\
\hline & $P S_{\text {leaf }}(g)$ & $20,49 \pm 3,44$ a & $21,65 \pm 8,78$ a & $28,91 \pm 12,25$ a & $23,07 \pm 12,73 \mathrm{a}$ \\
\hline & $M S_{\text {leaf }}(\%)$ & $51,65 \pm 2,49 a b$ & $45,37 \pm 6,48$ a & $57,11 \pm \mid 4,63$ b & $51,26 \pm 5,07 \mathrm{ab}$ \\
\hline & $P F_{\text {root }}(\mathrm{g})$ & $27,16 \pm 3,89 a$ & $30,19 \pm \mid 1,31$ a & $31,95 \pm 9,22 \mathrm{a}$ & $31,13 \pm 16,00 \mathrm{a}$ \\
\hline & $P S_{\text {root }}(g)$ & $13,53 \pm 1,83$ a & $14,04 \pm 7,48$ a & $15,63 \pm 5,20 \mathrm{a}$ & $14,57 \pm 9,95$ a \\
\hline \multirow{8}{*}{ 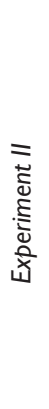 } & $M S_{\text {root }}(\%)$ & $49,91 \pm 2,62 \mathrm{a}$ & $41,54 \pm 15,66$ a & $49,33 \pm 8,28 \mathrm{a}$ & $42,21 \pm 16,94 \mathbf{a}$ \\
\hline & $\operatorname{IAF}\left(\mathrm{cm}^{2}\right)$ & $1149,6 \pm 31,7 \mathbf{a}$ & $1142,2 \pm 16,1$ a & $1727,3 \pm 176,6$ b & $1997,5 \pm 236,6$ b \\
\hline & $P F_{\text {leaf }}(g)$ & $20,5 \pm 0,5 \mathbf{a}$ & $20,4 \pm 0,2 \mathrm{a}$ & $30,9 \pm 3,1 \mathbf{b}$ & $35,7 \pm 4,2$ b \\
\hline & $P S_{\text {leaf }}(g)$ & $7,5 \pm 0,3 \mathbf{a}$ & $7,6 \pm 0,3 \mathbf{a}$ & $10,7 \pm 1,2 \mathbf{b}$ & $12, \mid \pm I, 6 \mathbf{b}$ \\
\hline & $M S_{\text {leaf }}(\%)$ & $36,4 \pm 0,8 \mathbf{a}$ & $37,3 \pm 0,9 \mathbf{b}$ & $34,6 \pm 1,0$ a & $33,8 \pm 0,9 \mathbf{a}$ \\
\hline & $P F_{\text {root }}(g)$ & $6,73 \pm 0,45 \mathrm{a}$ & $7,17 \pm 0,3 \mid$ ab & $7,43 \pm 0,4$ ab & $7,77 \pm 0,3 \mid \mathbf{b}$ \\
\hline & $P S_{\text {root }}(g)$ & $1,83 \pm 0,16 \mathbf{a}$ & $2,28 \pm 0,1 \mathbf{b}$ & $2,27 \pm 0,07$ b & $2,27 \pm 0,06 \mathbf{b}$ \\
\hline & $M S_{\text {root }}(\%)$ & $27,2 I \pm 0,8 \mathbf{a}$ & $31,75 \pm 0,1$ d & $30,55 \pm 0,7$ c & $29,21 \pm 0,5 \mathbf{b}$ \\
\hline
\end{tabular}

Uncommon letters in the same variable denote significant differences according to the LSD test (Minimum significant difference) for $P<0.05$

Citation: Di Barbaro, Horacio A, Silvana BM, et al. Effect of Azospirillum brasilense and mycorrhizal soil fungi on topinambur grown in a greenhouse.J Appl Biotechnol Bioeng. 2021;8(4): I04-II0. DOI: I0.15406/jabb.202I.08.0026I 
Fresh weight of leaves per plant: The highest production of foliar mass was observed in the topinambur plants from the inoculated treatments, establishing statistically significant differences in favor of the inoculated treatments compared to the controls (Table 3). But, only in one experiment in topinambur was no statistical significance recorded.

Percentage of dry matter of leaves: In the topinambur plants from treatments $\mathrm{T} 1$ and $\mathrm{T} 2$ the highest percentages of dry matter were obtained (Table 4). percentage: The highest root biomasses were obtained in the inoculated plants, registering significant statistical differences between the treatments in all the experiments. Regarding the percentage of dry matter of roots, only in one experiment of topinambur no differences with statistical significance were achieved (Table 4). Results show the root growth promoter activity of the microorganisms under study.

The evaluation of the complete plant during pot development showed a higher growth of the inoculated plants, observing statistically significant differences for the control plants in the variables percentage of dry matter, fresh and dry biomass (Table 4).

Table 4 Comparison of agronomic parameters of topinambur (fresh weight, dry weight and dry mass of whole plants) produced in greenhouse with unsterilized soil. (Experiment I: 7 months of planting; Experiment II: 3 months of planting)

\begin{tabular}{|c|c|c|c|c|c|}
\hline & \multirow{2}{*}{ Variable } & \multicolumn{4}{|l|}{ Treatments } \\
\hline & & Control & Azospirillum & Mycorrhizae & Azosp.+Myco. \\
\hline \multirow{3}{*}{$\overline{\frac{\dot{x}}{x}}$} & $P F(g)$ & $105,76 \pm 14,13$ a & $165,80 \pm 65,66 \mathbf{b}$ & $153,43 \pm 35,83 \mathbf{b}$ & $159,59 \pm 42,55$ b \\
\hline & PS (g) & $53,69 \pm 7,63 \mathbf{a}$ & $67,16 \pm 22,66 a b$ & $3,08 \pm \mid 4,92 \mathbf{b}$ & $66,34 \pm 27,28 \mathrm{ab}$ \\
\hline & MS (\%) & $50,73 \pm I, 30 \mathbf{b}$ & $41,76 \pm 10,75 a b$ & $49,69 \pm 15,14 a b$ & $40,2 I \pm 9,63 \mathbf{a}$ \\
\hline \multirow{3}{*}{$\begin{array}{l}= \\
\frac{\dot{d}}{\dot{x}}\end{array}$} & $P F(g)$ & $53,33 \pm 1,29 \mathbf{a}$ & $65,27 \pm 0,91$ a & $55,47 \pm 10,5$ a & $86,00 \pm 12,4 \mathbf{b}$ \\
\hline & PS (g) & $17,60 \pm 0,95 \mathbf{a}$ & $21,33 \pm 0,2 \mathbf{a b}$ & $24,37 \pm 1,67$ b & $28,83 \pm 4,1$ c \\
\hline & MS (\%) & $32,99 \pm 0,9 \mathbf{a}$ & $32,68 \pm 0,2 \mathbf{a}$ & $45,28 \pm 10,5$ b & $33,54 \pm 0,6 \mathbf{a}$ \\
\hline
\end{tabular}

Uncommon letters in the same variable denote significant differences according to the LSD test (Minimum significant difference) for $\mathrm{P}<0.05$

Root dry matter However, in one of the topinambur experiments, it was determined that the highest percentage of dry matter was observed in the control treatment (T0), with statistically significant differences for the the remaining treatments (Table 4).

In summary, with the application of the microbial consortium to the cultivation of topinambur, better vegetative behavior and greater production of tubers were obtained under greenhouse cultivation conditions.

\section{Discussion}

The results obtained showed an increase in the different variables of vegetable production evaluated (plant height, number of tubers, fresh weight, and dry weight of stems, roots, and tubers) due to the effect of inoculation with native microorganisms of $A$. brasilense and mycorrhizal fungi, registering significant statistical differences for the control plants without inoculation. Therefore, the highest productivity of this culture is obtained by microbial inoculation of the tubers at the time of implantation of the culture.

The microbial consortium used, made up of native bacterial, and fungal strains, generated the best results due to the greater intake of water and nutrients, and mainly nitrogen that can be incorporated into the soil by biological nitrogen fixation, since the bacterium $A$. brasilense has this capacity, in addition to synthesizing auxins and other phytohormones..$^{50}$ The greater uptake of water and nutrients, especially those that are not very mobile such as phosphorus, facilitate their availability and assimilation by plants. ${ }^{51-54}$ In addition, these microorganisms locate and colonize sites in the rootlets, which could potentially be occupied by phytopathogens..$^{55}$

The selection of effective microorganisms in promoting the growth of cultures is a great challenge. The adaptation to the environment to which they are introduced and the compatibility between the microorganisms that make up the microbial consortia and these with the plant, may be the factors that prevent their use in agricultural production.

This work contributes to making evident the potential of the selected microorganisms as an alternative to improve the nutrition and productivity of the topinambur crop. These results could support the possible use of microbial inoculants in the production of this crop, which would avoid or reduce the use of chemical fertilizers. They also indicate that there was a direct effect of microbial inoculation on the growth and yields of the topinambur culture.

\section{Conclusions}

The inoculations of "seed" tubers at the time of implantation of the topinambur (H. tuberosus) culture with the selected microorganisms generated a positive effect in greenhouse culture conditions and evaluated variables, improving their development and productivity due to the better and increased nutrition. Significant differences were detected in the variables evaluated due to the effect of the treatments applied to the topinambur crop. The harvest of the crops in the phenological stage of "delivery" and tuber maturity, together with the variables associated with the production of tubers (quantity, fresh weight, dry weight, yield, etc.) are the most consistent.

The application of the microbial consortium increased the potential of the culture, obtaining the best results, due to the co-inoculation with the consortium of $A$. brasilense and mycorrhizal fungi (T3), achieving increases in yield, far exceeding the controls. The application of microorganisms in studies, in the implantation of the culture of topinambur in greenhouse trials, allowed the establishment of beneficial relationships, ensuring survival, promoting the growth of plants in their first phases of growth fundamentally, and increasing the yield of crops.

The microbial inocula used in these experiments are native species, and due to their origin, they have generated more adequate 
adaptation mechanisms to the environmental conditions, for which it is estimated that this is one of the reasons for which promising results have been presented for the growth of the topinambur crop. This study is pioneering in the studied area, so it is considered very promising to obtain a higher production and innovate with the cultivation of topinambur, for its application with multiple purposes. Furthermore, to determine the effect of the interactions with the native microorganisms of the study soil, it is important to carry out the experiments under sterile soil conditions.

\section{Acknowledgments}

None.

\section{Conflicts of interest}

The authors declare that they have no known competing interests

\section{Funding}

None.

\section{References}

1. Cosgrove DR, Oelke DA, Doll JD, et al. Topinambur. Alternative Field Crops Manual. 1991.

2. Rebora C. Topinambur (Helianthus tuberosus L.): uses, cultivation and potential in the Cuyo region. Hort Argent. 2008;(63):27-37.

3. Altundag E, Ozturk M. Ethnomedicinal studies on the plant resources of east Anatolia, Turkey. Procedia - Soc. Behav Sci. 2011;19:756-777.

4. Gedrovica I, Karklina D, Fras A, et al. The non-starch polysaccharides quantity changes in pastry products where Jerusalem artichoke (Helianthus tuberosus L.) added. Procedia Food Sci. 2011;1:1638-1644.

5. Fawzi EM. Comparative study of two purified inulinases from thermophile Thielavia terrestris NRRL 8126 and mesophile Aspergillus foetidus NRRL 337 grown on Cichorium intybus L. Brazilian J Microbiol. 2011;42:633-649.

6. Taha HS, Abd El-Kawy AM, Abd El-Kareem Fathalla M. A new approach for achievement of inulin accumulation in suspension cultures of Jerusalem artichoke (Helianthus tuberosus) using biotic elicitors. $J$ Genetic Eng Biotechnol. 2012;10:33-38.

7. Takeuchi J, Nagashima T. Preparation of dried chips from Jerusalem artichoke (Helianthus tuberosus) tubers and analysis of their functional properties. Food Chem. 2011;126:922-926.

8. Ibarguren L, Calderon M, Tessaro S, et al. Sensory evaluation of the Jerusalem artichoke (Helianthus tuberosus L.) as food. ESTUARY. INTA, Argentina; 2019;45(2):204-210.

9. Bach V, Jensen S, Kidmose U, et al. The effect of culinary preparation on carbohydrate composition, texture and sensory quality of Jerusalem artichoke tubers (Helianthus tuberosus L.). LWT - Food Sci Technol. 2013;54:165-170.

10. Volpini-Rapina LF, Ruriko Sokei F, Conti-Silva AC. Sensory profile and preference mapping of orange cakes with addition of prebiotics inulin and oligofructose. LWT-Food Sci \& Technol. 2012;48:37-42.

11. Iraporda C, Rubel IA, Manrique GD, et al. Influence of inulin rich carbohydrates from Jerusalem artichoke (Helianthus tuberosus L.) tubers on probiotic properties of Lactobacillus strains. LWT-Food Sci Technol. 2019.

12. Tessaro SE. Food with high fructan content:purée of Jerusalem artichoke (Helianthus tuberosus L.). Thesis. Fac. De Cs. Agrarian. Univ. Nac. de Cuyo. Mendoza; 2014
13. Okada N, Kobayashi S, Moriyama K, et al. Helianthus tuberosus (Jerusalem artichoke) tubers improve glucose tolerance and hepatic lipid profile in rats fed a high-fat diet. Asian Pacific J of Trop Medic. 2007.

14. Ly J. Nitrogen and energy balance in pigs fed jerusalem artichokes (Helianthus tuberosus L.). Rev Comput de Produc Porcina. 2000.

15. Papi N, Kafilzadeh F, Fazaeli H. Use of Jerusalem artichoke aerial parts as forage in fat-tailed sheep diet. Small Rumin Res. 2019;174:1-6.

16. Yildiz G, Sacakli P, Gungor T. The effect of dietary Jerusalem artichoke (Helianthus tuberosus L.) on performance, egg quality characteristics and egg cholesterol content in laying hens. Czech J Anim Sci. 2006;51(8):349_ 354.

17. Denisow B, Tymoszuk K, Dmitruk M. Nectar and pollen production of Helianthus tuberosus L. - an exotic plant with invasiveness potential. Acta Bot Croat. 2019;78(2).

18. Parameswaran M. Geen energy from Jerusalem artichoke. Agric Sci. $1995 ; 8(5): 43-45$.

19. Berenji J, Sikora V. Variability ASd stability of tuber yield of Jerusalem artichoke (Helianthus tuberosus L.). Helia. 2001;24:25-32.

20. Kays SJ, Nottingham SF. Biology and chemistry of Jerusalem artichoke (Helianthus tuberosus L.). CRC Press. Taylor \& Francis Group 2008. 478 p.

21. Lima Verde Leal MR, Tarántola F, Roggiero A, Castro D, et al. Biomass para energy. Capítulo 5:Producao de etanol em regioes semi-áridas. UNICAMP Editora. 2008;113-131.

22. Lelio H, Rebora C, Gómez L. Potential for obtaining bioethanol from topinambur (Helianthus tuberosus L.) irrigated with urban wastewater. Rev FCA UNCuyo. 2009; XLI(1):123-133.

23. Pimsaen W, Jogloy S, Suriharn B, et al. Genotype by Environment (GxE) Interactions for Yield Components of Jerusalem Artichoke (Helianthus tuberosus L.). Asian J Plant Sci. 2010;9(1):11-19.

24. Chi ZM, Zhang T, Cao TS, et al. Biotechnological potential of inulin for bioprocesses. Bioresource Technol. 2011;102:4295-4303.

25. Reust W, Dutoit JP. Renewable raw materials and alternative crops:yield potential of Jerusalem artichoke, sweet sorghum and a spurge. Landwirtscharft-Schweiz. 1992;5(10):509-516.

26. Fernández J. Production costs of Jerusalem artichoke (Helianthus tuberosus L.) for ethanol production in Spanish irrigated lands. 1998

27. Showkat MM, Falck-Ytter AB, Strætkvern KO. Phenolic Acids in Jerusalem Artichoke (Helianthus tuberosus L.):Plant Organ Dependent Antioxidant Activity and Optimized Extraction from Leaves. Molec. 2019;24(18):3296.

28. Prusov AN, Prusova SM, Zakharov AG, et al. Potential of Jerusalem Artichoke Stem for Cellulose Production. Eurasian ChemTechnol J. 2019.

29. Rubel IA, Iraporda $\mathrm{C}$, Novosad $\mathrm{R}$, et al. Inulin rich carbohydrates extraction from Jerusalem artichoke (Helianthus tuberosus L.) tubers and application of different drying methods. Food Res Intern. 2018.

30. Yuan X, Cheng M, Gao M, et al. Cytotoxic constituents from the leaves of Jerusalem artichoke (Helianthus tuberosus L.) and their structure-activity relationships. Phytochem Lett. 2013;6:21-25.

31. Jeong GT. Catalytic conversion of Helianthus tuberosus L. to sugars, 5hydroxymethylfurfural and levulinic acid using hydrothermal reaction. Biom \& Bioen. 2015.

32. Bach V, Clausen MR, Edelenbos M. Production of Jerusalem Artichoke (Helianthus tuberosus L.) and Impact on Inulin and Phenolic Compounds. Vegetables and root crops. 2015;12:97-102. 
33. Sun PC, Liu Y, Yi YT, et al. Preliminary enrichment and separation of chlorogenic acid from Helianthus tuberosus L. leaves extract by macroporous resins. Food Chem. 2015;168:55-62.

34. Chen F, Long X, Yu M, et al. Phenolics and antifungal activities analysis in industrial crop Jerusalem artichoke (Helianthus tuberosus L.) leaves. Ind Crops \& Prod. 2013;47:339-345.

35. Willscher S, Jablonski L, Fona Z, et al. Phytoremediation experiments with Helianthus tuberosus under different $\mathrm{pH}$ and heavy metal soil concentrations. Hydrometal. 2017;168:153-158.

36. Judprasong K, Archeepsudcharit N, Chantapiriyapoon K, et al. Nutrients and natural toxic substances in commonly consumed Jerusalem artichoke (Helianthus tuberosus L.) tuber. Food Chem. 2018;238:173-179.

37. Marzec M, Gizińska-Górna M, Jóźwiakowski K, et al. The efficiency and reliability of pollutant removal in a hybrid constructed wetland with giant miscanthus and Jerusalem artichoke in Poland. Ecol Eng. 2019.

38. Klímek P, Meinlschmidt P, Wimmer R, et al. Using sunflower (Helianthus annuus L.), topinambour (Helianthus tuberosus L.) and cup-plant (Silphium perfoliatum L.) stalks as alternative raw materials for particleboards. Ind Crops \& Prod. 2016;92:157-164.

39. Sarasola AA, Rocca de Sarasola MA. Phytopathology. Modern course. Volume IV. Southern Hemisphere Editorial. Argentina; 1975.

40. Mrosk C, Forner S, Hause G, et al. Composite Medicago truncatula plants harbouring Agrobacterium rhizogenes-transformed roots reveal normal mycorrhization by Glomus intraradices. J Exp Bot. 2009;60(13):37973807.

41. Tarrand JJ, Krieg NR, Döbereiner J. A taxonomic study of the Spirillum lipoferum group, with descriptions of a new genus, Azospirillum gen nov. and two species, Azospirillum lipoferum (Beijerinck) comb. nov. and Azospirillum brasilense sp. nov. Can J Microbiol. 1978;24(8):967-980.

42. Döbereiner J, Baldani VLD, Baldani JI. How to isolate and identify diazotrophic bacteria from non-legume plants. Brasília: EMBRAPASPI. Itaguaí, RJ:EMBRAPA-CNPAB. 1995;11-60.

43. Caballero-Mellado J. The genus Azospirillum. In "Microbes online". (E. Martinez-Romero and J. Martínez-Romero). Univ Nac Autónoma de México. 2002;177-198.
44. Manacorda AM, Tables DP, Álvarez AS. Practical Manual of Microbiology. Environmental Microbiology I. Cap. 8: Microorganism count. 2007.

45. Sieverding E. Mycorrhiza Project. International Center for Tropical Agriculture. Cali. Colombia; 1983. 121 p.

46. McGonigle TP, Miller MH, Evans DG, et al. A new method which gives an objective measure of colonization of roots by vesicular-arbuscular mycorrhizal fungi. New Phytol. 1990;115:495-501.

47. Lal K, Subba Rao MA. Rapid Method of LeafArea Determination. Nature. 1951.

48. Di Rienzo JA, Casanoves F, Balzarini MG, et al. InfoStat version 2018. InfoStat Transfer Center, FCA, Univ. Nac. de Córdoba, Argentina; 2018.

49. Andrada H, Di Barbaro G, Paz de Arias I, et al. Productive evaluation of the Helianthus tuberosus crop for the agroclimatic conditions of Catamarca. Winter evaluation. ReBeA. 2011;1(2):159-160.

50. Larraburu EE, Yarte ME, Llorente BE. Azospirillum brasilense inoculation, auxin induction and culture medium composition modify the profile of antioxidant enzymes during in vitro rhizogenesis of pink lapacho. Plant Cell Tiss Organ Cult. 2016.

51. Kirk PM, Cannon PF, David JC, et al. Ainsworth and Bisby's Dictionary of the Fungi. 9th ed. CAB International, Wallingford, UK; 2001.

52. Selosse MA, Richard F, He X, et al. Mycorrhizal networks:des liaisons dangereuses? Trends Ecol Evil. 2006;621-628.

53. Harrison MJ. Signaling in the arbuscular mycorrhizal symbiosis. Annu Rev Microbiol. 2005;59:19-42.

54. Wang B, Qiu YL. Phylogenetic distribution and evolution of mycorrhizas in land plants. Mycorrhizahello. 2006.

55. Newsham KK, Fitter AH, Watkinson AR. Multi-functionality and biodiversity in arbuscular rmycorrhizas. Trends in Ecol Evol. $1995 ; 10: 407-411$. 